\title{
GENRE-BASED INSTRUCTION (GBI): The Concept and Its Application to Foreign Language Classroom
}

\author{
Oleh:Rita Erlinda*
}

\begin{abstract}
Since the implemetation of KBK and KTSP, the goals of teaching English at schools are emphasized on the mastery of four language competences-linguistic, strategic, sociolinguistic and actional-which will lead to the mastery of discourse competence. Those competences are realized in for language skills (listening, speaking, reading and writing) through the analysis of texts (genres). Therefore, one of the approaches to facilitate the accomplishment of the goals is Genre-based Instruction (GBI). This approach is mainly a language teaching program which is based upon Genre Analysis Technique. This technique deals with anaysing text, both spoken and written, in order to figure out social or commnicative functions, genre structures, lexico-grammatical features of particular genres. Consequently, the learners are able to use the language for appropriate situational and cultural contexts.
\end{abstract}

Key Words: genre, genre analysis, genre-based instruction (GBI), foreign language classroom, functional grammar

\section{INTRODUCTION}

ompetency-based curriculum,
known as Kurikulum Berbasis
Kompetensi $(\mathrm{KBK}), \quad$ and content-based curriculum, called as Kurikulum Tingkat Satuan Pendidikan (KTSP), focus on students' gaining in certain competencies, (Mulyasa, 2003: 39). Dealing with this issue, foreign language curriculum should consider students' ability to use language properly in a communicative event both situational and cultural contexts since it is influenced by many factors such as topic to be communicated, the discourse participants, and register used in both contexts. Moreover, the curriculum should emphasize to enable the students to gain for four language competences- linguistic competence, sociolinguistic competence, actional compe- tence, and strategic competence. These four competences then are poured in discourse competence. Pusat Kurikulum, Balitbang Depdiknas, (2003) claims that discourse competence can be defined as learner's competence to use language properly in a communicative event both in spoken and written forms.

In order to develop the discourse competence as the target of foreign language learning, teachers should have clear guidance of how to conduct their teaching in the classroom. To do this well, foreign language learning should use analysis of genres or kinds of text as basis of foreign language learning.

There are various genres that can be used to achieve standard of competency for English at senior high school level, such as descriptive, narrative, spoof/recount, procedure, report,

* Penulis adalah Lektor dalam Mata Kuliah Linguistic pada STAIN Batusangkar 
news item, anecdotes, exposition, explanation, discussion, commentary, and review. Analyzing these various genres can enable the students to understand and express interpersonal, ideational, and textual meaning in both interaction and monologue, Pusat Kurikulum, Balitbang Depdiknas (2003). The results from analyzing a genre serve as the instructional materials in GBI.

Genre-based Instruction (GBI) is based on the result of genre analysis. There are three characteristics of Genrebased Instruction (GBI)-social, generic structure, and lexico-grammatical fea-tures. First, examine the structural pat-tern of a certain text or genre to achieve the communicative purpose and the roles of the writer and the audience of the target text or genre, and the context in which the genre is used (social function). Second, examine the particular linguistic features in a specific text or genre (generic structure). Third, examine lexico-grammatical features of a spe-cific genre to identify the linguistic features chosen in a specific genre (lexico-grammatical features). Other considerations in genre analysis include the communicative purpose of the target genre.

In applying GBI, grammar is not taught in isolation from the communicative functions of the language. It is taught by analyzing the lexicogrammatical features of the target genre. It is neither taught as an end in itself, nor as the central focus of instruction, but as a means to an end-- achieving the social purposes of the genre that is the overarching focus of teaching. The genre-based material views grammatical form as intrinsically linked to communicative function, and seeks to help students understand the links between particular aspects of English grammar and their functions. This differs from traditional forms of grammar instruction. In conclusion, GBI offers grammar instruction as an integral part of the teaching of foreign language through analysis of genres.

Consequently, this article aims to answer the following questions:

1. What is Genre?

2. What is Genre Analysis?

3 . What is the relevance of genre in foreign language teaching?

4. What is Genre-based Instruction?

5. What is the position of Grammar in GBI?

6. How GBI can be applied in foreign language classroom?

\section{WHAT IS GENRE?}

The word genre comes from the French (and originally Latin) word for 'kind' or 'class'. The term is widely used in rhetoric, literary theory, media theory, and more recently linguistics, to refer to a distinctive type of text, (Chandler in Bradford-Watts, 2001). According to Swales (1990), a genre comprises a class of communicative events, the members of which share some set of commu-nicative purposes. His definition offers the basic idea that there are certain conventions or rules which are generally associated with a writer's purposes. For example, personal letters tell us about (their writers') private stories, film reviews analyze movies for potential viewers, and police reports describe what happened. Most genres use conventions related to communicative purposes, for example, argumentative essay em-phasizes its thesis. It aims at making an argument.

Related to the definition of genre, Bradford-Watts (2001) describes the following illustration: "everyone engages in a social or communicative event. If, for example, you go shopping for shoes, you will expect the interaction to be fairly consistent with your past experiences of shopping for 
shoes. You will expect some kind of acknow-ledgement or greeting, to have your questions answered about availability of your size and preferred color, to be told the price, and finally to be thanked for your business. Not all of these may occur (you may find the perfect size and color immediately and not need to ask any questions), and they may not occur in this order. If, however, you go shopp-ing for a car, you would expect this service encounter to be somewhat more complex, involving explanations of fea-tures and add-ons, as well as financing options."

In the shoe-shopping example above, your expectations are determined by your wanting to procure shoes (purpose) in the year $2000 \mathrm{AD}$ (rather than in the years $1500 \mathrm{BC}, 1945 \mathrm{AD}$, or 3000 AD), in Thailand (rather than Bali, Hong Kong, or Tehran), in a shop with a shop assistant (rather than a supermarket with a checkout, for example). If you change any of these conditions, the interaction between you and the person from whom you wish to procure the shoes would change--the text produced would be different.

This is similar for written texts: love letters to your life partner, advertisements for local plumbers, posted lists of rules for the use of the gym, essays, newspaper editorials, obituaries, and doctoral theses. Each of these examples is written at a time, in a place, for a purpose, by one or more writers for a defined reader.

The above illustration is supported by Gerot and Wignell (1995). They state,"a genre can be defined a culturally specific text type which result from using language (written or spoken) to (help) accomplish something." To understand this definition deeply, they give an example of what is called as a genre. Think, for example, of a typical doctor-patient consultation. This consultation has a purpose. It takes place through a series of stages, and uses language in particular ways. So, there is usually some sort of greeting; an invitation from the doctor for the patient to describe symptoms; an examination, during which doctor tells the patient what to do and maybe why. Then the doctor tells the patient what the problem is, if known, and how it will be treated. If not known, the doctor explains that a referral is necessary. The consultation closes with some kind of leave-taking. This is how it is done in an Englishspeaking culture. So, genres are culture specific; and have associated with them. They are (1) particular purpose, (2) particular stages, and (3) particular linguistic features."

From the description above, it can be concluded that genre refers to the distinctive type of text both in verbal (spoken) and written form. It is a communicative event that occurs at a particular time in a particular place and between particular people for a particular communicative purpose. Therefore, each genre uses particular stages (structural features) and linguistic features (lexico-gramatical features).

\section{WHAT IS GENRE ANALYSIS?}

Genre analysis is a developing multi-disciplinary approach to the study of texts, both verbal and written forms. Genre analysis is a tool to examine the communicative purpose (social function), linguistic features, and lexicogrammatical features of a target genre. In short, genre analysts look for the com-mon patterns of grammar usage, key vo-cabulary, and text structure in particular text types, Bradford-Watt (2001).

There are many examples of genre analysis. Bhatia (1993) analyses a wide range of written texts, including sales promotion letters, job applications, research article abstracts, introductory 
in student academic writings, legislative provisions, and legal cases. McCarthy (2000) describes close-contact verbal encounters at a hairdresser's. Kuiper and Flindall (2000) discuss the role of small talk and where it is situated in the service encounter genre at the supermarket in New Zealand. Several recent studies are concerned, for example, with the developing genres of the Internet. Giordano in Bardford-Watts (2001) discusses genres developing in chat rooms and discussion groups. BradfordWatts (2001) analyses online movie reviews and email confirmations of online orders. Both document the development of new genres. It is important to note that genres are not fixed. They change over time, reflecting changes in society.

\section{WHAT IS THE RELEVANCE OF GENRE TO FOREIGN LANGUAGE TEACHING?}

Paltridge (2001) states, "The notion of genre ...provides a basis for extending current syllabus models, as well as for selecting and sequencing syllabus items and, in turn, focusing on them in the language learning classroom", since it incorporates vocabulary and grammatical structures that are typically associated with functionalnotional approaches to syllabus design; a focus on situation, social activities, and topic that derives from situational and content-based syllabuses; and a focus on specific language learning tasks and activities that draws from task-based and procedural approaches to language teaching and learning.

In other words, using genre as a starting point in curriculum design by listing genres necessary for student understanding within a context--typical in content-based curricula--allows the teacher to (a) collect real samples of appropriate texts, (b) design activities to foster understanding of the genre, (c) draw attention to key vocabulary and grammatical structures associated with that genre, and (d) demonstrate to the students how these interact with the who, what, where, when, how, and why of the text in terms of situation and context, allowing the relationship between culture and language to be directly addressed. Tasks give students the opportunity to experiment with the gen-re, manipulating their texts to accom-modate changes which can be expected to occur with variation of contextual factors. Tasks also give teachers an opportunity to monitor students and take advantage of teachable moments that arise to increase student awareness of sociocultural factors which affect choice of form within the context. A genre-based course is, essentially, an outcome-based course, with the aim being explicit student awareness of and proficiency in the target genres. It allows teachers to focus on both form and meaning, as well as how meanings are made.

An important reason to consider genre-based instruction is that of empowerment: If students are able to understand, access and manipulate genres, they acquire "cultural capital" (Hammond \& Mackin-Horarick, 1999, in Paltridge, 2001). Not teaching this explicitly denies students the means to participate in and challenge the cultures of power they will encounter when interacting with members of the target culture.

\section{WHAT IS GENRE-BASED IN- STRUCTION (GBI)?}

Basically, Genre-based Instruction (GBI) is teaching language based on results of genre analysis. As stated above, genre analysis is the study of how language is used within a particular setting and is concerned with the form 
of language use in relation to meaning, Swales (1990). Bhatia (1993) states that genre analysis is a tool (1) to examine the structural organisation of texts by identifying the moves and strategies, and to understand how these moves are organised in order to achieve the com-municative purpose of the text. Genre analysis also (2) examines the text patterning or textualisation in genres to show statistical evidence of a particular linguistic feature in a specific genre and the specific features of the genre that the evidence textualises. Finally genre analysis (3) examines the lexico-grammatical features of genres to iden-tify the linguistic features chosen by expert users of the genre to realize the communicative purpose, and to explain these choices in terms of social and psychological contexts. Other considera-tions in genre analysis include the communicative purpose of the target genre, the roles of the writer and the audience, and the context in which the genre is used. The results from analyzing a genre serve as the instructional mate-rials in GBI.

\section{WHERE IS THE POSITION OF GRAMMAR IN GBI?}

Gerot and Wignell (1995) claim that the notion 'genre' and 'grammar' are closely linked. Consequently, grammar instruction is an integral part of the teaching of the genre. The grammar instruction not only is explicit, but also involves some degree of student analysis. Grammar is not taught in isolation from the communicative functions of the language. It is also neither taught as an end in itself, nor as the central focus of instruction, but as a means to an end-- achieving the social purposes of the genre that is the overarching focus of teaching.

The genre-based material views grammatical form as intrinsically linked to communicative function, and seeks to help students understand the links between particular aspects of English grammar and their functions. Moreover, the focus of grammar does not remain focused at sentence level, but moves beyond to how sentence-level patterns fit into natural whole texts in communication. In all these senses, the teaching of grammar is 'functional'.

The approach to grammar as 'functional' is influenced by the systemic functional linguistics of Michael Halliday (1985). Her theory sees language as a system of resources for making meaning in context. Thus, the grammar of a language, or what systemic functional linguists call the 'lexico-grammar', is seen not merely as a set of rules or patterns of syntax, but a set of agreed-on conventions intimately related to possible meanings, determined by contexts of situation embedded in contexts of culture in which language is used.

In the materials of genres in GBI, lexico-grammatical features are provided. Lexico-gramatical features of various genres are integral to those genres, for it is through the lexicogrammatical choices that meaning is built up in a text. Different genres deploy the resources for meaningmaking through grammar in different ways. For example, Recounts, which retell an event, tend to use past tense, Material Processes, and particular participants. On the other hands, the purpose of Report is to describe the way things are in the world, and so they tend to use Relational Processes and generic participants. Students are taught these features and a language for talking about language (a metalanguage) in the context of learning how these features contribute to the overall meaning of texts they are reading or writing. 


\section{HOW CAN GBI BE APPLIED IN THE FOREIGN LANGUAGE CLASSROOM?}

Swales (1990) notes that there is a curriculum cycle in Genre-based Instruction (GBI). It consists of four stages. They are (1) content exploration, (2) text exploration, (3) joint construction, and (4) individual application, as follows:

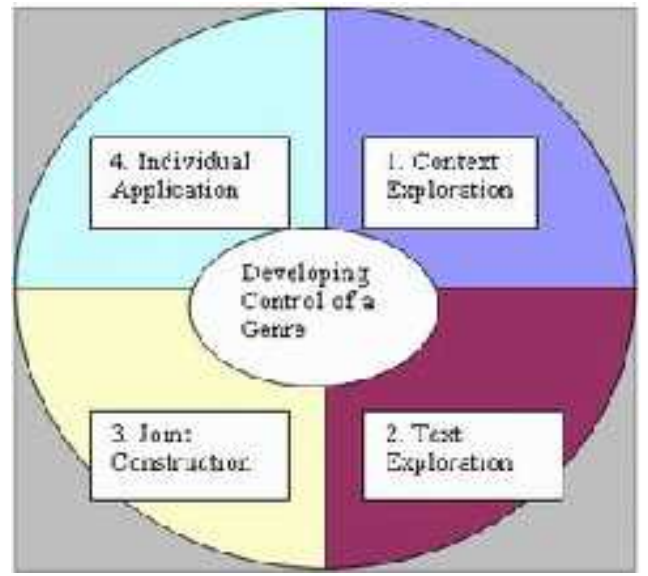

Figure 1: The Curriculum Cycle in GBI

The first stage is Context Exploration. 'Context' refers to the possible contexts of situation in which the chosen text-type or genre may be used. This phase resembles the prelistening/reading/speaking/writing phase that has come to be typical in commu-nicative language teaching, and the activities that may be carried out do indeed resemble typical pre-activities in skills-based teaching. One primary aim of this phase is to help students to become aware of and understand the social purpose of the chosen genre, as well as other contextual factors influenc-ing the production of the texts that they will examine as models, and the texts that they may be required to produce in speech or writing. Another important aim of the context exploration phase, from the teacher's point of view, is to establish the learners' 'actual develop-ment' or starting point.
The next stage is text exploration. The aims of this phase are to familiarize the learners with the target text-type or genre, and to draw attention to organizational and linguistic features common-ly found in texts belonging to it. Model texts play a crucial role in this phase. Model text is called objectregulation. Analyzing such model texts, pedagogical activities to make explicit the features of the text-type are carried out. These may include a gamut of established 'commu-nicative' activities, such as the re-assem-bling of 'jigsaw' texts or information gap exercises, but the tasks are deliberately constructed in such a way as to highlight the salient lexical and grammatical features. Thus, the tasks aim to be at least implicitly 'analytical' in nature, and not just to facilitate interaction as an end in itself. Of course, more explicitly analytical work is also possible: for example, students may be asked to 'hunt' for and highlight all instances of a specific grammatical form. Direct teach-ing by the instructor is also an option, in order to make the features obvious to the learners. How the formal features work to help the text-type or genre achieve its purposes are also discussed or explored, the teacher playing a key role in othersregulation throughout this phase.

Others-regulation continues and takes centre-stage in the next stage, joint construction, as the third phase. Here, referring to the model text or texts, and making use of the knowledge and awareness gained from the exploration of the text, the students work with the teacher to construct their own texts (spoken or written) in the text-type or genre (or, in the case of listening and reading, to construct an understanding of the new text). This can take forms varying from teacherfronted whole-class co-construction of a single text on the board, to small-group or pair construction with the teacher 
helping each group or pair by turn, to teacher conferencing with individual students. In the case of writing, as with process approaches, the texts may go through a few rounds of drafting, editing, and re-drafting. The model texts continue to provide object-regulation, while others-regulation comes from not only the teacher but also from other students, as more expert peers guide others, or as students refer each other to features in the models, and to points raised in the text exploration stage.

What is to be noted in both the text exploration and joint construction phases is that while there is much oral interaction taking place, its nature and intention is different from that of most forms of communicative language teach-ing. Where the interactive activities in the latter are often designed to simulate real life interaction, directed at providing opportunities for talking in the language, the talk here is about using language, and is focused on a collaborative effort to learn to accomplish a purpose in the language.

The last stage in the Cycle is individual application. As the name suggests, it requires learners to work individually and independently, for example, in the case of writing, to produce individual essays. Ideally, this is carried out only after the students have successfully produced a jointly con-structed text or understanding of a text. This phase then provides the opportunity for self-regulation. What each learner produces can, of course, be further re-cycled through further othersregulation (e.g. peer editing, teacher feedback), until the learner attains a desired level of attainment.

In the following, there is a small example how to apply GBI in the classroom. Report text entitled "Wombat" is as material for teaching writing skill.

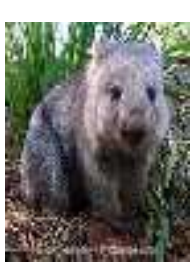

\section{WOMBAT}

Wombats

are

mammals. There are two kinds of wombat. There is the common wombat and the hairy nosed wombat.

Wombats are brown. They are covered in fur to keep them warm. Wombats have small legs and big bodies. Wombats can grow up to 4 feet long. They can weigh up to 15 kilos and 37.5 kilos

The common wombat lives in coastal forest. Wombats live in grassy areas so they can feed on grass. Wombats live in holes called burrows.

Wombats tend to sleep all day and be active during the night. Wombat feed on grass, small bushes and root.

Recall that genres are staged, goal-directed, and purposeful. Thus for any given text, we can ask: (1) what is its so-cial purpose or function or goal? (2) through what stages does it achieve that goal (generic structure)?, and (3) what lexico-grammatical and discourse choices are involved in the above? The three important aspects or characteristics of Report text (genre) can be concluded in the following table:

\begin{tabular}{|c|c|c|}
\hline $\begin{array}{l}\text { Social } \\
\text { Function }\end{array}$ & $\begin{array}{l}\text { Generic } \\
\text { Structure }\end{array}$ & $\begin{array}{c}\text { Lexico- } \\
\text { grammatical } \\
\text { Features }\end{array}$ \\
\hline $\begin{array}{l}\text { To describe } \\
\text { the way things } \\
\text { are, with } \\
\text { reference to a } \\
\text { range of } \\
\text { natural, man } \\
\text { made and } \\
\text { social } \\
\text { phenomena in } \\
\text { our } \\
\text { environment }\end{array}$ & 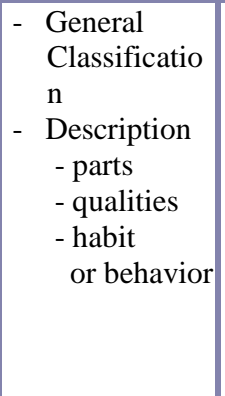 & $\begin{array}{l}\text { - Focus on generic } \\
\text { participants } \\
\text { - Use of } \\
\text { Relational } \\
\text { Processes } \\
\text { - Use of Simple } \\
\text { Present Tense } \\
\text { - No Temporal } \\
\text { sequence }\end{array}$ \\
\hline
\end{tabular}

Table 1: Characteristics of Report Text (Genre)

Now, let's apply GBI in the foreign language classroom according to the above cycles: 


\section{The first stage; Context Exploration}

On this stage, the teacher tries to explore possible contexts (situational and cultural) related to the text "wombat". This stage resembles preteaching activities. The aim of this stage is to help the students become aware of and understand the social purpose of Report genre. As stated above, the social function of text "Wombat" is to describe the way wombat are, with reference to its appearance, habit and behavior. In this case, the teachers follow the following steps, namely:

a. The teacher shows the picture of wombat to the students.

b. The teacher inform students the social purpose of Report text

c. The teacher asks some questions to students related the characteristics of wombat

d. The teacher develop students vocabulary related to "wombat life"

\section{The second stage; Text Exploration}

On this stage, the teacher tries to familiarize the learners with the Report text, as target text-type or genre. The teacher can use the following the steps, namely:

a. The teachers draw learners' attention to generic structure commonly found in Report text. As stated above, report genre consists of general classifica-tion-- tells what phenomena under discussion is and description--.tells what the phenomena under discussion is like in terms of parts (and their function), qualities, and habits of behaviors if living; uses, if non-natural. In familiarize students with its generic structure, the teacher divide the report text, "Wombat" into several parts based on its generic structure.

- The first paragraph is the general classification of wombat.
- The second paragraph is the description of wombat appearance

- The third paragraph is the description of wombat habitat

- The fourth paragraph is the description of wombat behaviors

b. The teachers divide the students into four Jigsaw groups. Each group will discuss different paragraph to obtain its generic structure.

c. The teachers draw learners' attention to linguistic features (lexicogramma-tical features) commonly found in Report text by underlining or highlighting them to make the features are more obvious to the learners. For example, Relational processes are

\section{The third stage: Joint Construction}

This stage aims at exploring Report text as model text to the students. In this case, the teachers guide the students to understand the text and see the features of Report text are more obvious. To do this well, the teachers can use the following ways:

d. The teachers ask each group to present the generic structure of each paragraph: the description of wombat appearance, habit, and behavior

e. The class discusses the generic structures of the whole text, "Wombat" until the students get the regulation from "Wombat" as model text.

f. The teachers conclude the generic structure of "Wombat" as model of report text.

\section{The fourth stage: Individual Explo- ration}

This stage requires learners to work individually and independently. The learners write another report text by applying its generic structure and considering linguistic features of report 
text. The learners can be successful to write new text after they have been successfully produced a jointly constructed text or understanding the text. To do this well, the teacher can follow the steps below:

g. The teachers ask the students to choose an object to be described and reported.

h. The students identify the characteristics of the chosen object.

i. The students individually write a new report text by applying the regulation studied from the model text given.

\section{CONCLUSIONS}

Genre-based Instruction (GBI) is teaching language based on results of genre analysis both in spoken and written form. Specifically, genre analysis is a tool to examine (1) the structural organization of text by

\section{BIBLIOGRAPHY}

Bhatia, V. 1993. Analysing genre: Language use in professional settings. New York: Longman.

Bradford-Watts, K. 2001. Six texts, two genres: An analysis. Bulletin of Research Institute for Foreign Education, No.10, Kyoto Tachibana Women's University.

Crane, C., Galvanek J., Liamkina O., \& Ryshina-Pankova, M. 2002, March. Genre: Where art thou? Tracing the role of genre in the foreign language curriculum. Retrieved from uccllt.ucdavis.edu/hli/papers/Cran e,etal.Irvine2002Paper.htm.

Gerot, Linda and Wignell, Peter. 1995. Making Sense of Functional Grammar. Sydney: Tanya Stabler identifying the moves and strategies, and to understand how these moves are organized in order to achieve the communicative purpose of the text; (2) the text patterning or textualization in genre to show a parti-cular linguistic feature; (3) the lexico-grammatical features to identify the linguistic features chosen by expert users of the genre to realise the commu-nicative purpose, and to explain these choices in terms of social and psycho-logical contexts; and (4) the commu-nicative purpose of the target genre, the roles of the writer and the audience, and the context in which the genre is used.

There are four steps in applying GBI based on written text analysis in foreign language classroom. They are (1) context exploration; (2) text exploration; (3) joint construction and (4) individual application.

Halliday, M.A.K. 1985. An Introduction to Functional Grammar. Great Britain: Edward Arnold.

Departemen Pendidikan Nasional. 2003. Standar Kompetensi Mata Pelajaran Bahasa Inggris untuk SMA dan MA. Jakarta: Balitbang Depdiknas.

Kuiper, K., \& Flindall, M. 2000. Social rituals, formulaic speech and small talk at the supermarket checkout. In J. Coupland (Ed.), Small talk. Singapore: Pearson.

McCarthy, M. 2000. Mutually captive audiences: Small talk and the genre of close-contact service encounters. In J. Coupland (Ed.), Small talk. Singapore: Pearson. 
Mulyasa, E. 2003. Kurikulum Berbasis

Kompetensi:

Konsep,

Karakteristik, dan Implementasi.

Bandung: PT. Remaja

Rosdakarya.

Paltridge, B. 2001. Genre and the language learning classroom. Ann Arbor: University of Michigan Press.

Swales, J. M. 1990. Genre analysis: English in academic and research settings. Cambridge: Cambridge University Press. 
